\title{
Absorption and excretion of cephalexin by the newborn infant
}

\author{
ROSEMARY BOOTHMAN, MARGARET M. KERR, MONICA J. MARSHALL, and \\ W. L. BURLAND*
}

From the Department of Child Health, University of Glasgow, and The Queen Mother's Hospital, Glasgow; and the Departments of Microbiology and Clinical Research, Glaxo Laboratories, Greenford, Middlesex

Boothman, R., Kerr, M. M., Marshall, M. J., and Burland, W. L. (1973). Archives of Disease in Childhood, 48, 147. Absorption and excretion of cephalexin by the newborn infant. Blood levels and urinary excretion of cephalexin were studied in newborn infants who were given 3-day courses of the antibiotic prophylactically. These infants were born to mothers with intrapartum pyrexia or with membranes ruptured for 72 hours or longer.

Adequate blood levels of cephalexin were achieved after oral administration of $50 \mathrm{mg} / \mathrm{kg}$ every 12 hours, provided that the infant was not vomiting. Absorption was slower and probably less complete than in the adult. Persistently high levels of the antibiotic in the serum were associated with the low level of renal function normal in newborn infants.

It is suggested that oral cephalexin may be substituted for intramuscular cephaloridine in the newborn infant, but only when oral feeding has been firmly established.

Cephaloridine, both alone and with streptomycin, has been shown to be safe and effective for the prevention and treatment of infection in the newborn period (Burland and Simpson, 1967; Burland, Simpson, and Samuel, 1970; Gould, 1970; Keay and Fleming, 1970; Keay, Syme, and Barnes, 1967). These antibiotics are given by intramuscular injection every 12 or 24 hours, and the route ensures that blood and tissue levels are adequate and sustained. Cephalexin resembles cephaloridine in that it is a semisynthetic antibiotic derived from cephalosporin C but, unlike cephaloridine, it is well absorbed when given by mouth. To be effective in the newborn infant an orally administered antibiotic must be retained and well absorbed. Cephalexin, moreover, is bactericidal to a broad range of Gram-positive and Gram-negative organisms (Foord et al., 1969; Nakazawa et al., 1969) including those commonly encountered in the immediate newborn period. Marget (1971) found cephalexin to be well tolerated and without toxicity in infants. We decided therefore to measure the absorption and excretion of the antibiotic in the newborn infant.

Received 19 June 1972.

*Present address: Servier Laboratories Limited, Percival House, Pinner Road, Harrow, Middx.

\section{Method}

Infants born to mothers with intrapartum pyrexia or with ruptured membranes for 72 hours or more were considered to be at risk from infection. They were given cephalexin, in the form of a syrup, immediately after birth and for 3 days. Blood samples for cephalexin assay were taken at various intervals after the first dose of antibiotic. One $5 \mathrm{ml}$ venous sample of blood was obtained from a peripheral vein or by fontanelle tap from each infant during the ccurse of treatment. Blood was immediately centrifuged and the serum stored at $-4{ }^{\circ} \mathrm{C}$. Urine was collected from a number of male infants for 24 hours during the second or third day of treatment, to determine the urinary excretion of the antibiotic. The samples were collected only from male infants for convenience. The total volume passed was measured and $10 \mathrm{ml}$ samples were stored at $-4^{\circ} \mathrm{C}$. In an initial investigation 40 infants were given $15 \mathrm{mg} / \mathrm{kg}$ cephalexin every 8 hours. In a second series, 30 infants received $50 \mathrm{mg} / \mathrm{kg}$ every 12 hours.

\section{Results}

Dosage $15 \mathrm{mg} / \mathrm{kg}$ 8-hourly. Group 1. The levels of cephalexin in the serum of this group of infants, at $1 \frac{1}{2}, 4,6$, and 8 hours after the first dose of the antibiotic, are shown in Fig. 1. The proportions of a day's dose excreted in the urine during 24 hours by 13 male infants are shown in 


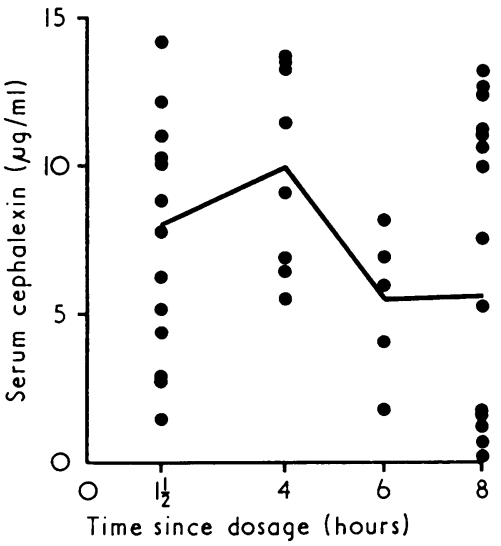

Fig. 1.- Mean and individual serum cephalexin levels in newborn infants after one $15 \mathrm{mg} / \mathrm{kg}$ dose by mouth.

Table I. The average amount of a day's dose excreted in this group of infants was $30 \%$. Some regurgitation occurred in 5 infants, each of whom consequently had serum cephalexin levels below the average figure.

TABLE I

Urinary excretion of cephalexin by newborn male infants given $15 \mathrm{mg} / \mathrm{kg}$ 8-hourly by mouth

\begin{tabular}{|c|c|c|c|}
\hline \multirow{2}{*}{$\begin{array}{c}\text { Group } 1 \\
\text { infants }\end{array}$} & \multicolumn{2}{|c|}{ Urine } & \multirow{2}{*}{$\begin{array}{c}\% \text { of } \\
\text { total daily } \\
\text { dose excreted } \\
\text { in } 24 \mathrm{hr}\end{array}$} \\
\hline & $\begin{array}{c}24 \mathrm{hr} \\
\text { volume } \\
(\mathrm{ml})\end{array}$ & $\begin{array}{l}\text { Concentration } \\
\text { cephalexin } \\
(\mu \mathrm{g} / \mathrm{ml})\end{array}$ & \\
\hline $\begin{array}{r}1 \\
2 \\
3 \\
4 \\
5 \\
6 \\
7 \\
8 \\
9 \\
10 \\
11 \\
12 \\
13\end{array}$ & $\begin{array}{r}124 \\
38 \\
70 \\
86 \\
93 \\
58 \\
100 \\
50 \\
18 \\
44 \\
90 \\
127 \\
40\end{array}$ & $\begin{array}{r}465 \\
139 \\
433 \\
511 \\
587 \\
531 \\
481 \\
462 \\
1113 \\
1518 \\
468 \\
768 \\
766\end{array}$ & $\begin{array}{l}39 \\
5^{\star} \\
25 \\
37 \\
37 \\
35 \\
25 \\
17 \\
11^{\star} \\
34 \\
41 \\
59 \\
17\end{array}$ \\
\hline
\end{tabular}

$\star$ Vomited.

Dosage $50 \mathrm{mg} / \mathrm{kg}$ 12-hourly. Group 2. The levels of cephalexin in the serum of the second group of infants, at 1, 2, 3, 4, 8, and 12 hours after the first dose of the antibiotic, are shown in Fig. 2. Urinary excretion from 10 male infants during 24 hours is shown in Table II. Some minor regurgitation occurred in 5 infants. One, who vomited more severely, had no assayable cephalexin in the serum 1 hour after dosage. The average urinary excretion of a day's dose of cephalexin was $39 \%$

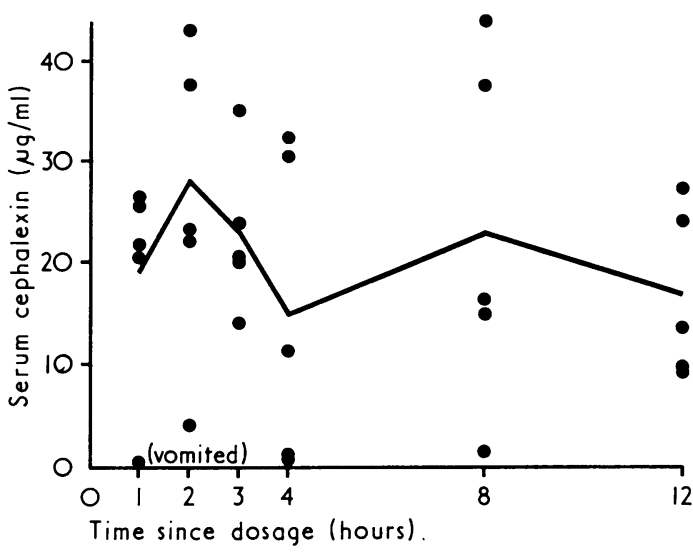

FIG. 2.-Mean and individual serum cephalexin levels in newborn infants after one $50 \mathrm{mg} / \mathrm{kg}$ dose by mouth.

for this group. Swabs were taken from nose, throat, groin, and rectum of each infant at birth and at $3,5,7,14$, and 21 days for bacteriological culture. Stomach aspirate at birth was also cultured. A range of Gram-negative and Grampositive organisms was identified but no clinical infections occurred in the treated infants.

Over a period of 6 months, as part of a separate bacteriological survey, 28 separate isolations of Pseudomonas pyocyanea occurred in the neonatal unit where the investigations were undertaken. The isolations came from infants aged 1 to 14 days and from various body sites. 10 of these infants were among those who had received cephalexin, 10 others had received ampicillin and cloxacillin, and $8 \mathrm{had}$ received no antibiotic. In only one instance was illness in the infant considered to be related to the presence of the organism.

TABLE II

Urinary excretion of cephalexin by newborn male infants given $50 \mathrm{mg} / \mathrm{kg}$ 12-hourly by mouth

\begin{tabular}{|c|c|c|c|}
\hline \multirow{2}{*}{$\begin{array}{l}\text { Group } 2 \\
\text { infants }\end{array}$} & \multicolumn{2}{|c|}{ Urine } & \multirow{2}{*}{$\begin{array}{c}\% \text { of } \\
\text { total daily } \\
\text { dose excreted } \\
\text { in } 24 \mathrm{hr}\end{array}$} \\
\hline & $\begin{array}{l}24 \mathrm{hr} \\
\text { volume } \\
\text { (ml) }\end{array}$ & $\begin{array}{c}\text { Concentration } \\
\text { cephalexin } \\
(\mu \mathrm{g} / \mathrm{ml})\end{array}$ & \\
\hline $\begin{array}{r}1 \\
2 \\
3 \\
4 \\
5 \\
6 \\
7 \\
8 \\
9 \\
10\end{array}$ & $\begin{array}{l}14 \cdot 5 \\
49 \\
38 \\
120 \\
58 \\
105 \\
73 \cdot 5 \\
71 \\
51 \cdot 5 \\
37\end{array}$ & $\begin{array}{l}4067 \\
1365 \\
2486 \\
1832 \\
1441 \\
2373 \\
2283 \\
1810 \\
1318 \\
3847\end{array}$ & $\begin{array}{l}24 \\
25 \\
30 \\
64 \\
20 \\
66 \\
51 \\
36 \\
18 \\
54\end{array}$ \\
\hline
\end{tabular}


No untoward effects were noted in either group of infants during cephalexin treatment. All the infants, whose birthweights ranged from $2 \mathrm{~kg}$ to $4.3 \mathrm{~kg}$, remained free from infection during the period of treatment.

\section{Discussion}

There is at present no general agreement regarding the necessity for prophylactic antibiotic therapy in the newborn after a birth which has been possibly complicated by uterine infection. Many clinicians, remembering the problems in maternity units in the $1950 \mathrm{~s}$, are probably reluctant to abandon prophylaxis when there has been prolonged rupture of membranes and/or fetal distress (Bound, Butler, and Spector, 1956). Davies (1971) advises that prophylactic antibiotics should be withheld from the majority of infants, even though they emerge from an apparently infected environment, and treats only those who appear ill at birth.

However, since infection in the newborn may be overwhelming or so insidious in onset as to make prompt diagnosis difficult, it remains the practice at this hospital to give newborn infants a suitable antibiotic for 3 days when the membranes have been ruptured for more than 72 hours, or when there has been maternal pyrexia of $37.0^{\circ} \mathrm{C}$ or more, during labour.

The serum levels of cephalexin achieved after a dosage of $15 \mathrm{mg} / \mathrm{kg}$ 8-hourly were lower than the average minimum inhibitory concentration (MIC) for many of the Gram-negative organisms encountered in the neonatal period. In contrast, the levels achieved after $50 \mathrm{mg} / \mathrm{kg}$ 12-hourly resembled more closely those seen in adults receiving $1 \mathrm{~g}$ doses (O'Callaghan, Toothill, and Robinson, 1971), though peak levels occurred later, at about 2 hours after dosage, indicating slower absorption by the infants. The high levels of cephalexin in the serum 8 or 12 hours after a single dose reflect a phenomenon seen with other antibiotics, including cephaloridine (Burland and Simpson, 1967), in newborn infants and result from reduced renal function, normal in this age group. Higher serum and tissue levels of cephalexin may be required in certain infections and could be achieved with higher dosage. No changes in bacterial isolations were experienced as a result of introducing cephalexin into the neonatal unit; the isolations of Ps. pyocyanea were equally distributed between infants receiving cephalexin, those receiving other antibiotics, and those receiving none.

Urinary excretion of cephalexin in 24 hours ranged widely from 5 to $66 \%$ of the total daily dose. The lowest amounts excreted by infants taking
$15 \mathrm{mg} / \mathrm{kg}$ 8-hourly were from the ones with the lowest serum levels and in whom regurgitation had occurred. Urinary excretion of the antibiotic must be related to the amount of drug absorbed and its persistence at significant levels in the serum and tissues. The excretion of antibiotic by the infants studied was below that expected from adults with normal renal function. This probably reflects the limited powers of absorption and renal excretion seen in newborn infants, especially within the first 24 hours of life. On the basis of the urinary excretion levels obtained it appears that some 50 to $60 \%$ of the administered dose of cephalexin is absorbed by the newborn infant. 9 infants were bled at various intervals after multiple doses of cephalexin. Table III shows that there was no significant accumulation of antibiotic in the serum.

\section{TABLE III}

Serum cephalexin in newborn infants after multiple $50 \mathrm{mg} / \mathrm{kg}$ doses given 12-hourly by mouth

\begin{tabular}{c|c|c|c}
\hline $\begin{array}{c}\text { Group 2 } \\
\text { infants }\end{array}$ & $\begin{array}{c}\text { No. of } \\
\text { previous } \\
\text { doses }\end{array}$ & $\begin{array}{c}\text { Time since } \\
\text { last dose } \\
(\mathrm{hr})\end{array}$ & $\begin{array}{c}\text { Serum } \\
\text { cephalexin } \\
(\mu \mathrm{g} / \mathrm{ml})\end{array}$ \\
\hline 1 & 2 & 12 & $8 \cdot 8$ \\
2 & 3 & 3 & $28 \cdot 0$ \\
3 & 3 & 8 & $15 \cdot 9$ \\
4 & 3 & 12 & $15 \cdot 9$ \\
5 & 3 & 12 & $24 \cdot 4$ \\
6 & 4 & 4 & $24 \cdot 1$ \\
7 & 6 & 1 & $14 \cdot 1$ \\
8 & 6 & 4 & $21 \cdot 6$ \\
9 & 6 & 8 & $27 \cdot 7$ \\
\hline
\end{tabular}

It is not the purpose of this communication to suggest that, for the newborn infant, an orally administered antibiotic is to be preferred to one given by intramuscular injection. Many paediatricians advise that even prophylactic antibiotics should be given by the intramuscular route for at least the first 24 hours of life. It seems reasonable, therefore, to substitute oral cephalexin for intramuscular cephaloridine in the newborn infant only when oral feeding has been firmly established.

\section{REFBRENCES}

Bound, J. P., Butler, N. R., and Spector, W. G. (1956). Classification and causes of perinatal mortality. British Medical fournal, 2, 1191.

Burland, W. L., and Simpson, K. (1967). Administration of cephaloridine to the newborn infant. Postgraduate Medical fournal, 43, Suppl. 112.

Burland, W. L., Simpson, K., and Samuel, P. D. (1970). Combining cephaloridine and streptomycin for the treatment and prophylaxis of neonatal infections. Postgraduate Medical fournal, 46, Suppl. 85.

Davies, P. A. (1971). Bacterial infection in the fetus and newborn. Archives of Disease in Childhood, 46, 1. 
Foord, R. D., O'Callaghan, C., Muggleton, P. W., and Currie, J. P. (1969). Cephalexin-bacteriology, pharmacology and toxicology. Proceedings of Symposium 'Clinical Evaluation of Cephalexin', Royal Society of Medicine, London, 2 and 3 June, p. 3. Ed. by R. D. Foord. Glaxo Laboratories Ltd., Greenford.

Gould, J. C. (1970). The use of cephaloridine in an antibiotic policy trial. Postgraduate Medical fournal, 46, Suppl. 83.

Keay, A. J., and Fleming, J. G. (1970). Further studies of the use of cephaloridine in the control of infection in the newborn. Postgraduate Medical fournal, 46, Suppl. 81.

Keay, A. J., Syme, J., and Barnes, P. M. (1967). Cephaloridine in the treatment and prophylaxis of infection in the newborn. Postgraduate Medical fournal, 43, Suppl. 105.

Marget, W. M. (1971). Special aspects of cephalosporin therapy in infants and children. Postgraduate Medical fournal, 47, Suppl. 54.

Nakazawa, S., Ono, H., Nishino, T., and Kawabe, H. (1969). In vitro laboratory evaluation of cephalexin and cephaloglycin. Proceedings of Symposium 'Clinical Evaluation of Cephalexin', Royal Society of Medicine, London, 2 and 3 June, p. 7. Ed. by R. D. Foord. Glaxo Laboratories Ltd., Greenford.

O'Callaghan, C. H., Toothill, J. P. R., and Robinson, W. D. (1971). A new approach to the study of serum concentrations of orally administered cephalexin. Fournal of Pharmacy and Pharmacology, 23, 50 .

Correspondence to Dr. W. L. Burland, Servier Laboratories Limited, Percival House, Pinner Road, Harrow, Middx.

The following articles will appear in future issues of this journal:

Family with probable achondrogenesis and lipid inclusions in fibroblasts. By R. Laxova, P. T. Ohara, M. A. C. Ridler, and J. A. D. Timothy.

Serum monoclonal immunoglobulins in childhood. By F. Danon and M. Seligmann.

Terbutaline in children with asthma. By J. Leegaard and S. Fjulsrud.

Congenital malformations of human dermatoglyphs. By T. J. David.

Heparin therapy in meningococcalsepticaemia. By J. Hunter.

Mini exchange plasma transfusion. By P. J. Kearney.

Nephrotic syndrome in congenital syphilis. By R. Suskind, J. A. Winkelstein, and G. A. Spear.

Severe cutaneous reactions to phenytoin. By K. P. Dawson. 